\title{
Pemberdayaan masyarakat untuk umkm melalui pelatihan penyusunan proposal usaha dan analisis laporan keuangan UMKM di Kabupaten Kampar
}

\author{
Julita* \\ Jurusan Akuntansi, Fakultas Ekonomi dan Bisnis, Universitas Riau \\ *Julita@lecturer.unri.ac.id
}

\begin{abstract}
Abstrak. Tujuan kegiatan ini adalah agar pelaku UMKM dapat menyusun proposal usaha dan mampu menganalisislaporankeuangansehinggaterwujud UMKM sebagaiusaha yang efisien, sehat dan memilikipertumbuhan yang tinggi, mampu menjadi kekuatan ekonomi rakyat dan memberikan sumbangan yang besar bagi pembangunan ekonomi nasional. Metode kegiatan pengabdian ini adalah dengan metode survei secara langsung kepada pelaku UMKM tanpa adanya pengumpulan peserta secara bersamaan. Metode ini dipilih dengan mempertimbangkan keamanan bersama karena masih dalam suasana pandemi Covid-19. Tahapan kegiatan pengabdian ini dimulai dengan menjelaskan kendala yang sering dihadapi oleh pelaku UMKM, kemudian menjelaskan tentang pentingnya proposal usaha, tips dan trik menyusun proposal usaha, serta pentingnya menganalisis laporan keuangan. Hasil yang dicapai telah memberikan keterampilan dan menambah pengetahuan para pelaku UMKM khususnya di Kabupaten Kampar tentang penyusunan proposal usaha serta analisis laporan keuangan meskipun dalam keadaan dan kondisi yang terbatas akibat adanya pandemi Covid-19.
\end{abstract}

Kata Kunci: proposal usaha, analisis laporan keuangan, UMKM

\begin{abstract}
Abstrack.The aim of this activity is to Micro-Small and Medium Enterprises (MSMEs) be able to compile Business Proposals and be able to analyze financial statements, so that the realization of MSMEs becomes an efficient, healthy and high-growth business, and able to become the people's economic strength and make a large contribution to national economic development. The method of this service activity is the direct survey method for MSMEs without gathering participants, this method was chosen by considering mutual security because it is still in Covid-19 pandemic. The stages of this service activity begin by explaining the obstacles that are often faced by MSMEs, then explaining the importance of business proposals, tips and tricks for preparing business proposals, and the importance of financial statements analyzing. Results achieved: has provided skills and knowledge to MSMEs, especially in Kampar regarding Business Proposals and Financial Statement Analysis even though in limited due to the Covid-19 pandemic.
\end{abstract}

Keywords: business proposals, financial statement analysis, MSMEs

To cite this article: Julita. 2020. Pemberdayaan masyarakat untuk umkm melalui pelatihan penyusunan proposal usaha dan analisis laporan keuangan UMKM di Kabupaten Kampar. Unri Conference Series: Community

Engagement 2: 106-111. https://doi.org/10.31258/unricsce.2.106-111

(C) 2020 Authors

Peer-review under responsibility of the organizing committee of Seminar Nasional Pemberdayaan Masyarakat 2020 


\section{PENDAHULUAN}

Sejarah telah menunjukkan bahwa Usaha Mikro Kecil Menengah (UMKM) di Indonesia mampunbertahan dan berkembang walau krisis ekonomi telah melanda negeri ini sejak tahun 1997.Bahkan UMKM menjadi katup penyelamat bagi pemulihan ekonomi bangsa karena kemampuannya memberikan sumbangan yang cukup signifikan pada PDB maupun penyerapan tenaga kerja.UMKMtelah terbukti tahan banting menghadapi krisis seperti yang pernah terjadi pada 2012 dan pelambatan pertumbuhan yang terjadi pada 2015. UMKM berhasil menjadi payung bagi Indonesia dalam menghadapi badai ekonomi. Dalam kondisi krisis akibat pandemi Covid-19 ini diharapkan UMKM mampu tetap bertahan kembali.

Berdasarkan data Sensus Ekonomi dari Badan Pusat Statistik pada 2016 menunjukkan besarnya kontribusi UMKM. UMKM menyerap hingga 89,2\% dari total tenaga kerja, menyediakan hingga 99\% dari total lapangan kerja, menyumbang60,34\% dari total PDB nasional, menyumbang 14,17\% daritotal eksporserta menyumbang 58,18\% dari total investasi.(https://www.kompas.com/).Sementara itu, berdasarkan hasil Sensus Ekonomi (SE2016) pencacahan lengkap, jumlah Usaha Mikro Kecil (UMK) di Indonesia 26,26 juta usaha atau memiliki kontribusi 98,33\%.Di Provinsi Riau jumlah UMKM terbanyak pertama berada di KotaPekanbaru dengan jumlah 68.728 UMKMdisusulposisi kedua Kabupaten Kampar dengan jumlah UMKM sebanyak 45.446 UMKM.Meski memiliki jumlah yang relatif besar,UMKM di Kampar mempunyai berbagai persoalan yang antara lain persoalan permodalan dan marketing. (https://www.metroriaucom/)

Dari sekian banyak permasalahan UMKM yang terjadi di Indonesia,beberapa permasalahan yang dihadapi oleh UMKM yang berhubungan dengan kemudahan pengajuan kredit antara lain: (1) minimnya modal, hasil survei yang dilakukan oleh Pricewaterhouse Coopers, menunjukkan 74\% UMKM di Indonesia belum mendapatkan akses pembiayaan; (2) pengelolaan keuangan yang belum efisien, hal tersebut berakibat pada pengelolaan keuangan yang tidak efisien; (3) tidak memiliki izin usaha resmi, sehingga menghambat laju usaha. Mayoritas UMKM mengalami keterbatasan pengetahuan mengenai aspek legalitas dan perizinan usaha, termasuk persyaratan dan proses pengurusannya.

Tidak dapat dipungkiri bahwa UMKM memiliki peran besar bagi perekonomian bangsa, namun besarnya peran UMKM tersebut tidak sejalan dengan kisah sukses UMKM. UMKM di Indonesia masih sulit untuk naik kelas dan tumbuh pada level yang lebih tinggi. Permasalahan modal masih menjadi masalah klasik yang sering dihadapi oleh pelaku UMKM. Berkaitan dengan masalah terbatasnya permodalan, UMKM membutuhkan dukungan dari lembaga pembiayaan termasuk perbankan.

Pemerintah melalui perbankan telah memberikan dukunganakses permodalan dengan adanya KUR (Kredit Usaha Rakyat). KUR dimaksudkan untuk memberi pembiayan modal yang efektif untuk UMKM dan menjadi jalan keluar untuk mempermudah akses permodalan.Berdasarkan data dari Bank Indonesia (BI) yang dikutip dari laman (finansial.bisnis.com), penyaluran kredit kepada sektor UMKM pada Juni 2019 tercatat sebesar Rp1.019,8 triliun atau naik 11,6\% (year of year) dibandingkan dengan bulan sebelumnya Rp1.019,8 triliun. Akan tetapi program KUR ini masih tidak memenuhi target dan kurang termanfaatkan dengan baik. Salah satu penyebabnya adalah kurangnya persyaratan untuk pengajuan kredit tersebut. Yang antara lain harus adanya proposal usaha dan laporan keuangan UMKM. Oleh sebab itu, diperlukan sebuah program yang bisa memberi masukan bagi UMKM agar memiliki output yang terukur dan jelas. Sehingga dapat mengatasi permasalahan tersebut.

Pemerintah Indonesia melalui PP No 17 Tahun 2013 menyatakan tentang adanya kewajiban bagi pelaku usaha kecil untuk melakukan pencatatan akuntansi. Ikatan Akuntan Indonesia sudah menyiapkan Standar Akuntansi Keuangan untuk UMKM yang dinamakan denganSAK-EMKM(Standar AkuntansiKeuanganEntitas Mikro, Kecil dan Menengah) yang resmi diberlakukan efektif 1 Januari 2018. Menurut Mulyaga (2016) dengan membuat laporan keuangan sesuai dengan SAK EMKM, pemilik usaha juga dapat membuka kesempatan untuk meminjam modal dari perbankan. Karena salah satu syarat penting untuk mengajukan akses pendanaan ke bank adalah usaha tersebut telah menyusun laporan keuangan.

Minimnya pengetahuan dan perhatian pada pentingnya mempersiapkan administrasi usaha beserta legalitasnya telah menyebabkan perlambatan dalam perkembangan usaha UMKM. Kemampuan memperluas pasar, atau menambah jenis produk, termasuk meningkatkan cara berproduksi menjadi rendah. Akses permodalan baik berupa suntikan dana dari lembaga keuangan maupun kerjasama usaha dengan para investor menjadi tersendat. Dampaknya perkembangan usaha menjadi stagnan dan lambat laun cenderung menurun.

Menilik dari persoalan klasik yang masih terus terjadi pada kelompok usaha UMKM, perlu dilakukan kembali penyuluhan mengenai peyusunan proposal usaha dan analisis laporan keuangan. Khalayak sasaran kegiatan kali ini adalah UMKM di Kabupaten Kampar yang terdiri dari UMKM di bidang kuliner, pertanian, 
perikanan, kerajinan dan lainnya. Dipilihnya kelompok sasaran tersebut dengan pertimbangan jumlah pelaku UMKM di Kabupaten Kampar sangat besar sebanyak 45.446 UMKMdan potensi sumber daya alam Kabupaten Kampar yang sangat baik.

Berdasarkan permasalahan diatas perlu diadakan kegiatan pelatihan penyusunan proposal usaha dan analisis laporan keuangan. Kegiatan ini diharapkan dapat memberi bekal kepada para pelaku UMKM untuk dapat menyusun proposal usaha nya serta mampu menganalisis laporan keuangan. Tujuannya menjadikan UMKM memiliki daya saing tinggi dan mampu menjadi penyelamat bagi pemulihan ekonomi bangsa serta penyerapan tenaga kerja.

\section{KAJIAN LITERATUR}

\section{Pemberdayaan masyarakat}

Paradigma pembangunan yang lebih berpihak kepada rakyat mengandung arti penting bagi penciptaan masa depan. Pemahaman akan paradigma itu penting artinya bagi pemilihan teknik sosial termasuk bagaimana pemberdayaan masyarakat dilakukan secara tepat untuk mencapai tujuan-tujuan yang mementingkan rakyat. Kegiatan pemberdayaan masyarakat harus mampu mengembangkan teknik-teknik pendidikan tertentu yang imajinatif untuk menggugah kesadaran masyarakat.

Pemberdayaan masyarakat haruslah membantu masyarakat agar mampu mengembangkan diri atas dasar inovasi-inovasi yang ada, ditetapkan secara partisipatif, yang pendekatan metodenya berorientasi pada kebutuhan masyarakat sasaran dan hal-hal yang bersifat praktis, baik dalam bentuk layanan individu maupun kelompok. Peran petugas pemberdayaan masyarakat sebagai outsider people dapat dibedakan menjadi 3 bagian yaitu peran konsultan, peran pembimbingan dan peran penyampai informasi. Dengan demikian peran serta kelompok sasaran (masyarakat itu sendiri) menjadi sangat dominan.

\section{Proposal usaha}

Proposal usaha adalah dokumen tertulis yang disiapkan oleh wirausahawan yang menggambarkan semua unsur yang relevan. Baik itu internal maupun eksternal mengenai proyek baru, atau proposal usaha yang merupakan dokumen tertulis berisi usaha baru yang sedang direncanakan. Proposal usaha harus asli dan realistis, jika tidak pemodal atau investor akan ragu dengan proposal yang diajukan. Proposal yang dibuat tidak boleh menyalin dari proposal-proposal orang lain. Proposal usaha mencakup sasaran dan strategi. Sasaran disini adalah apa yang dicapai perusahaan, sedangkan strategi adalah arah tindakan untuk mencapai sasaran usaha.

\section{Akuntansi dan laporan keuangan UMKM}

Akuntansi adalah proses sistematis untuk mengolah transaksi menjadi informasi keuangan yang bermanfaat bagi para penggunanya Akuntansi digunakan oleh entitas untuk menghasilkan informasi keuangan dalam wujud laporan keuangan. Laporan keuangan akan digunakan oleh entitas untuk menentukan berbagai macam kebijakan. Informasi yang didapatkan dari laporan keuangan antara lain: (1). informasi kinerja keuangan entitas; (2)informasi perubahan jumlah modal pemilik dalam suatu entitas;(3) informasi posisi keuangan entitas terkait dengan sumber dana dan jenis penggunaan dana; (4) informasi pemasukan uang (kas) dan pengeluaran uang (kas).

\section{Analisis laporan keuangan}

Analisis laporan keuangan merupakan suatu proses untuk mengetahui posisi keuangan, hasil operasi dan perkembangan suatu perusahaan dengan cara mempelajari hubungan dari dataatau faktor keuangan serta kecenderungan yang terdapat dalam laporan keuangan ataupun dalam laporan keuangan komparatif. Dengan melakukan analisis terhadap laporan keuangan, informasi dan data keuangan yang diinginkan akan mudah dimengerti serta dapat dijadikan sebagai dasar dalam mengambil keputusan. Analisis laporan keuangan mempelajari hubungan dan kecenderungan posisi keuangan dan hasil operasi serta perkembangan perusahaan.

\section{Kinerja keuangan}

Kinerja keuangan diartikan sebagai prestasi organisasi atau perusahaan yang dinilai secara kuantitatif dalam bentuk uang yang dilihat, baik dari segi pengelolaan, pergerakan maupun tujuannya. Kinerja keuangan perusahaan yang tergambar dari laporan keuangan menjadi perhatian utama bagi pemakai laporan keuangan tersebut. Prestasi pelaksanaan program yang dapat diukur akan mendorong pencapaian prestasi tersebut. Pengukuran prestasi yang dilakukan secara berkelanjutan memberikan umpan balik untuk upaya perbaikan secara terus menerus dan pencapaian di masa yang akan datang. Suatu laporan keuangan belum dapat 
memberikan suatu informasi yang berguna apabila tidak dilakukan analisis terhadapnya. Analisis keuangan adalah cara yang paling banyak digunakan untuk menghubungkan satu pos dengan pos-pos lainnya dalam laporan keuangan dan memberikan gambaran yang jelas antarpos tersebut. Salah satu alat analisis yang paling mudah untuk digunakan adalah analisis rasio keuangan. Analisis ini dilakukan dengan membandingkan rasio keuangan antartahun dan juga dengan pertimbangan dari para analis. Dengan menggunakan analisis rasio dimungkinkan untuk menentukan tingkat solvabilitas, likuiditas, keefektifan operasional serta derajat keuntungan suatu perusahaan (Munawir, 2007).

\section{METODE PENERAPAN}

Dalam upaya mencapai tujuan dari kegiatan pengabdian ini, maka metode pelaksanaan dijabarkan sebagai berikut.

\section{Sesi survei}

Tahap awal, tim pelaksana mengadakan persiapan dengan melakukan survei untuk mengidentifikasi masalah para pelaku UMKM khususnya terkait masalah Penyusunan Proposal Usaha dan Analisis Laporan Keuangan.

\section{Sesi pelaksanaan kegiatan}

Tahap pelaksanaan, pada tahap ini dilaksanakan kegiatan penyuluhan pentingnya Penyusunan Proposal Usaha dan Analisis Laporan Keuangan. Selanjutnya pendampingan, dengan cara penyajian materi dan praktik pembuatan proposal pengajuan kredit dan Analisis Laporan Keuangan.Penyampaian materi dilakukan dengan mengedepankan teknik pendekatan diskusi interaktif dan disesuaikan dengan tingkat pengetahuan pelaku UMKM, agar materi yang disampaikan dapat lebih diterima.

\section{Sesi evaluasi}

Para pelaku UMKM dievaluasi secara tertulis maupun lisan untuk mengetahui tingkat pemahaman dari materi yang diberikan. Evaluasi yang dilakukan berupa tanya jawab dengan peserta melalui media komunikasi.

\section{HASIL DAN PEMBAHASAN}

Tingginya kasus pandemi Covid-19 di Kabupaten Kampar pada bulan September 2020 menjadikan kegiatan pengabdian ini tidak dapat dilaksanakan dengan mengumpulkan pelaku UMKM pada satu tempat. Sehingga Kegiatan Pemberdayaan Masyarakat ini dilaksanakan dengan metode survei langsung ataudoor to door. Metode ini dipilih dengan mempertimbangkan faktor kesehatan dan keamanan. Dengan tetap mematuhi Protokol Covid-19 tim pengabdian mendatangi para pelaku UMKM secara langsung untuk melaksanakan wawancara singkat terkait masalah-masalah yang sering dihadapi oleh UMKM. Tim telah mempersiapkan materi dalam bentuk modul pelatihan yang sederhana dan mudah dipahami untuk para UMKM yang didatangi. Melalui media modul ini tim memberikan penjelasan secara sistematis mengenai solusi atas masalah yang dihadapi oleh UMKM yang didatangi. Selain itu tim pengabdian juga memberikan kesempatan untuk berdiskusi dan berkonsultasi secara online dengan menggunakan media komunikasi whatsapp. Kegiatan pengabdian ini dilaksanakan pada Hari Sabtu, 12 September 2020 dengan mendatangi pelaku UMKM secara langsung dengan tetap mematuhi Protokol kesehatan Covid-19.
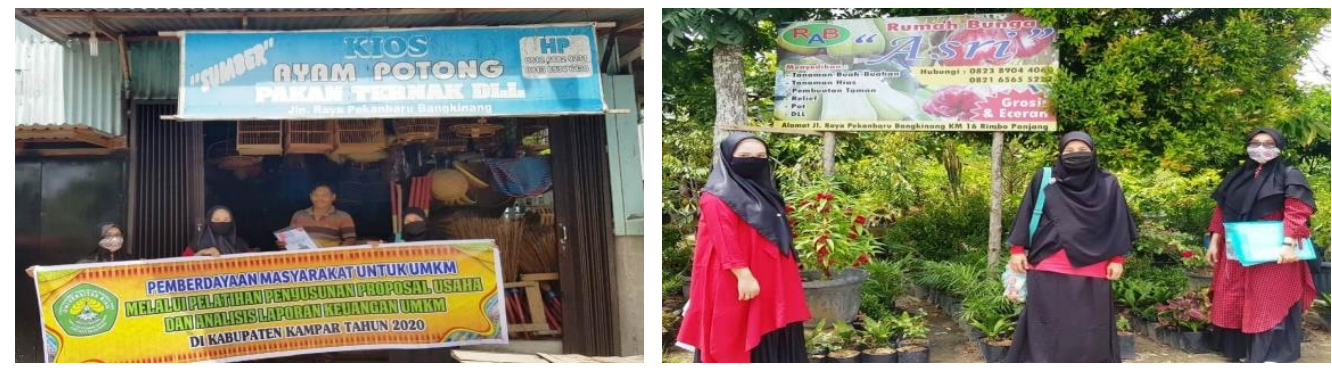

Gambar 1. Pelaksanaan kegiatan pengabdian.

Pemecahan masalah dilakukan dengan metode penyuluhan dan penyajian materi secara singkat.Pada awalnya tim pengabdian melakukan diskusi singkat terkait kendala yang sering dihadapi oleh pelaku UMKM.Ditemukan permodalan masih menjadi kendala klasik yang dihadapi oleh pelaku UMKM. Tim 
menjelaskan secara singkat terkait manfaat penyusunan proposal usaha termasuk cara menyusun, tips maupun trik penyusunannya.Tim juga menjelaskan secara singkat beberapa alat analisis yang dapat digunakan untuk mengukur kinerja keuangan dengan mudah. Pada saat kegiatan, timpengabdian memberikan modul pelatihan yang telah disusun dengan bahasa yang mudah dipahamidan diterapkan serta nomor handphone agar pelaku UMKM dapat berkonsultasi secara online.

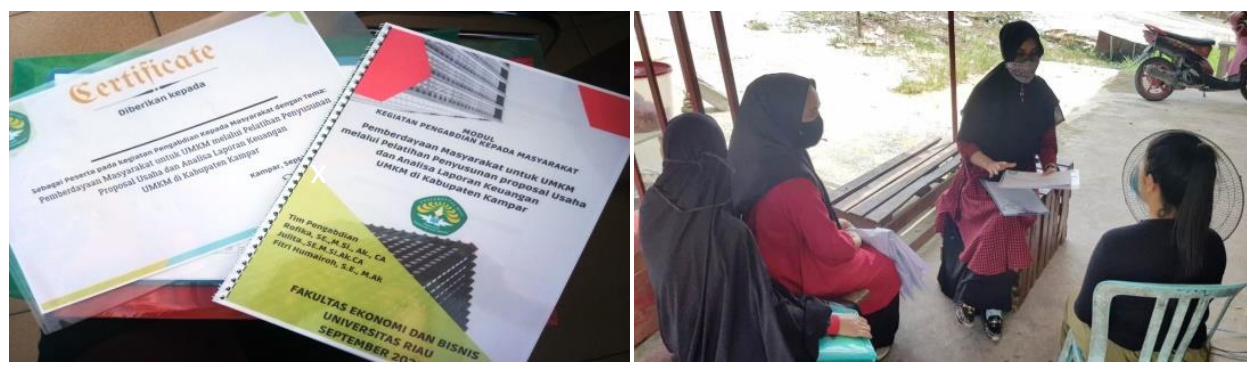

Gambar 2. Modul Pelatihan dan Kegiatan diskusi dengan pelaku UMKM

Secara umum pelaku UMKM sangat mengapresiasi kegiatan ini, karena menjadi tambahan pengetahuan dan ilmu bagi mereka serta dapat diterapkan dalam usaha yang sedang dijalankan. Para pelaku UMKM antusias mendengarkan penjelasan materi pada kegiatan ini, meskipun terkendala akibat pandemi. Adanya kegiatan ini memberikan semangat baru bagi pelaku UMKM bahwa permasalahan terkait permodalan dapat diselesaikan antara lain dengan pengajuan kredit ke lembaga keuangan serta membangun kerjasama usaha dengan para investor. Dilihat dari kondisi Pelaku UMKM di Kab. Kampar, maka materi tentang Penyusunan Proposal Usaha dan Analisis Laporan Keuangan menjadi salah satu hal yang penting untuk diketahui oleh pelaku UMKM. Dengan adanya proposal usaha mereka dapat mengakses permodalan, dengan menganalisis Laporan Keuangan, merekaakantahu kinerja usahanya.

Meskipun terkendala Pandemi Covid-19 tak menghilangkan semangat tim untuk tetap bisa berkontribusi demi perkembangan UMKM. Para pelaku UMKM akhirnya tahu tentang Manfaat Proposal Usaha, Menyusun Proposal Usaha, Tips dan Trik Menyusun Proposal usaha serta mampu menganalisis Laporan Keuangan.

\section{KESIMPULAN}

Kegiatan Pemberdayaan Masyarakat untuk UMKM Melalui Pelatihan Penyusunan Proposal Usaha dan Analisis Laporan Keuangan UMKM Di Kabupaten Kampar dilaksanakan sesuai dengan apa yang diharapkan meskipun masih dalam pandemi covid-19. Hal ini dapat dilihat dari respon positif para pelaku UMKM. Diharapkan ke depan kegiatan pelatihan dan pendampingan serupa dapat diselenggarakan lagi dalam rangka meningkatkan pengetahuan dan keterampilan pelaku UMKM dalam menyusun proposal usaha serta analisis Laporan Keuangan guna mengakses permodalan di lembaga perbankan maupun lembaga keuangan lainnya. Dengan proposal yang baik serta didukung dengan kemampuan menganalisis Laporan Keuangan diharapkan terwujudnya UMKM sebagai usaha mandiri yang efisien, sehat dan memiliki pertumbuhan yang tinggi, sehingga mampu menjadi kekuatan ekonomi rakyat dan memberikan sumbangan yang besar bagi pembangunan ekonomi nasional.

\section{UCAPAN TERIMAKASIH}

Syukur Alhamdulillah kami panjatkan kepada Allah SWT yang atas RahmatNya kegiatan Pengabdian ini dapat terlaksana dengan baik dan lancar. Tak lupa ucapan terimakasih kepada semua pihak yang terlibat dalam kegiatan ini. Kepada Fakultas Ekonomi dan Bisnis Universitas Riau kami sampaikan apresiasi telah memberikan pendanaan kepada kegiatan ini. Kami juga mengucapkan terima kasih kepada Kepala Dinas Koperasi dan UKM serta masyarakat Kabupaten Kampar tempat kami melaksanakan kegiatan ini. Semoga kegiatan ini dapat memberikan manfaat dan keberkahan untuk sesama. Aamiin Ya Rabbal alamiin 


\section{DAFTAR PUSTAKA}

Adi. 2019. Pemkab Kampar Berkomitmen Kembangkan UMKM, https://www.metroriau.com/berita/4404/2020-03-01/Pemkab-KamparBerkomitmen-Kembangkan-UMKM.html. Diakses pada 13 April 2020.

Andrian Permana.2020. Permasalahan UMKM. https://seoanaksholeh.com/bisnis/permasalahan-umkm. Diakses 13 April 2020

Aris Achmad. 2019. Penyaluran Kredit UMKM Melejit pada Juni 2019, https://finansial.bisnis.com/read/20190731/90/1130856/penyaluran-kredit-umkm-melejit-pada-juni-2019.diakses 13 April 2020

Arum Sutrisni. 2019. Peran UMKM dalam perekonomian Indonesia https://www.kompas.com/skola/read/2019/12/20/120000469/peran-umkm-dalam-perekonomianindonesia?page=all. Diakses 13 April 2020

Bustan, J., Divianto, D., \& Setiawan, H. 2017. Pelatihan Dan Pendampingan Pembuatan Proposal Pengajuan Kredit Bank Bagi Para Pedagang Pasar Tradisonal Sukawinatan Palembang. Comvice: Journal of community service, $1(1), 9-22$.

Fadhila Gebby.s https://riau.antaranews.com/berita/80571/jumlah-umkm-di-pekanbaru-mencapai-67728 diakses pada 13 April 2020.

Hadiwijaya, H., Febrianty, F., \& Darmawi, D. 2020. Pendampingan Manajemen Usaha dan Permodalan pada UKM Batu Bata. CARADDE: Jurnal Pengabdian Kepada Masyarakat, 2(2), 353-359.

Ikatan Akuntan Indonesia. 2016. SAK EMKM. Jakarta: Salemba Empat.

Munawir. AnalisisLaporan Keuangan. Yogyakarta: Liberty, 2007

Peraturan Pemerintah (PP) No. 17 Tahun 2013. Pelaksanaan Undang-undang Nomor 20 Tahun 2008 tentang Usaha Mikro Kecil dan Menengah

Rahmawati, T., \& Puspasari, O. R. 2017. Implementasi SAK ETAP dan Kualitas laporan keuangan UMKM terkait akses modal Perbankan. Jurnal Kajian Akuntansi, 1(1).

Susilo, Y. S. (2010). Peran perbankan dalam pembiayaan UMKM di provinsi DIY. Jurnal keuangan dan perbankan, 14(3), 467-478.

Zamora, Ramon. 2016. Pemberdayaan Masyarakat Untuk UMKM Melalui Pelatihan Penyusunan Studi Kelayakan Dan Proposal Usaha. Jurnal Dimensi. 